\title{
Construction Cost Analysis of Retaining Walls
}

\author{
Aikaterini Alexiou, Dimos Zachos, Nikolaos Alamanis, Ioannis Chouliaras, Grigorios \\ Papageorgiou
}

\begin{abstract}
Retaining walls are relatively rigid walls used to support the ground laterally so that it can be held at different levels on both sides [1]. Retaining walls are considered all technical works, which allow the implementation of a sharp change in the level of the earth's surface, in such a way that the ground-construction system presents limited displacement or is marginally restrained. Support structures are mainly used in cases of disruption of soil continuity resulting from an excavation, below the natural surface of the ground, such as when building roads in a difficult geographical terrain with steep slopes. It is also common for them to be used in the construction of basements in urban areas, when there are other buildings or roads around the perimeter. In special cases, functional reasons impose the local elevation of the ground surface with grounding in the area around the construction, such as on bridge piers or in port projects, so it becomes necessary to support the soil mass. Finally, the construction of retaining walls becomes necessary to stabilize and protect natural slopes that present kinematic instability.
\end{abstract}

The purpose of the present work is to compare the cost of constructing three retaining walls (gravity, cantilever, braced) subject to identical ground pressures. The retaining walls were designed using the same finite element software (GEO5), taking into account common parameters for the soil stress, the strength properties of the soil mass, the wall material as well as the diameter of the reinforcing steel bars, so that the results can be absolutely comparable. The market research that followed produced interesting conclusions on the comparison of the cost estimates for the three retaining walls.

Keywords: infrastructure support, retaining walls, construction cost, comparative analysis, infrastructure management.

\section{INTRODUCTION}

Slopes are defined as inclined natural or artificial soil or rock formations. This slope is the cause of its extreme instability due to the presence of shear stresses. As Terzaghi (1969) pointed out, soil masses, which are located behind a sloping surface or behind an open pit, tend to move downward and outward under the influence of gravity [2].

Revised Manuscript Received on April 25, 2020.

* Correspondence Author

Aikaterini Alexiou.*, Civil Engineer T.E. (Technological Educational Institute of Thessaly, 2017).

Dimos Zachos, Civil Engineer T.E. \&amp; Mechanical Engineer T.E. (Technological Educational Institute ofThessaly).

Dr. Nikolaos Alamanis., $\mathrm{PhD}$ in Stability of Slopes (University of Thessaly, Dept. of Civil Engineering)

Dr. Ioannis Chouliaras., Professor, University of Thessaly, Larissa, Greece. Civil Engineer (Democritus University of Thrace, 1980).

Dr. Grigorios Papageorgiou., Assistant Professor, University of Thessaly, Larissa, Greece.

(C) The Authors. Published by Blue Eyes Intelligence Engineering and Sciences Publication (BEIESP). This is an open access article under the CC BY-NC-ND license (http://creativecommons.org/licenses/by-nc-nd/4.0/)
The magnitude of the lateral earth pressure is dependent on the shear strength characteristics of the soil, the lateral strain conditions, the pore water pressures and the state of equilibrium of the soil. These in turn depend on drainage conditions, the interaction between the soil and the wall and on the magnitude and nature of relative displacements [3]. A retaining wall is a wall that provides lateral support for a vertical or near-vertical slope of the soil. It is a common structure used in many construction projects [4]. In the present work, retaining walls were studied and resolved in specific soil conditions. This study was conducted using the GEO5 geotechnical software [5]. GEO5 is a series of software designed to solve geotechnical problems, based on both classical analytical methods and the Finite Element Method (FEM).

\section{METHODOLOGY- LITERATURE REVIEW}

In the introduction and in section III, there is a historical and general reference to the lateral support structures and classification of their mechanisms. Subsequently, in section IV, retaining walls simulations as well as cases and types of support are presented in detail. For this construction cost analysis, three retaining wall simulations, a Gravity wall, a Cantilever wall, and a Braced wall were created. These walls are studied for specific soil conditions in order to evaluate the final construction costs. In Section V, carrying out a construction cost analysis investigation for the three types of retaining walls (Gravity Wall, Cantilever Wall and Braced Wall) from which useful results are extracted is presented as well. Finally, sections VI and VII provide suggestions and conclusions drawn from the above research. Regarding the references, it should be noted that [1] - [4] provide historical as well as recent time data for retaining walls. Source [5] refers to geotechnical software GEO5 which is based on the Finite Element Method (FEM). Sources [6] - [9] (mentioned in the text) were used to reinforce the theoretical background of the text as slopping surfaces and retaining walls are one of the most important areas of soil mechanics and geotechnical engineering research. The figures present and describe briefly types of walls while sources [10], [11], [12] (mentioned in the text) provide better support for suggestions and conclusions. Finally, it should be emphasized that the construction cost analysis for the three retaining wall simulations (with the desired range of calculation: $2<\mathrm{FS}<2.4$ ), is completely original and first published, and the results have led to very useful conclusions in seeking solutions for the comparison of the cost estimation.

Published By:

Blue Eyes Intelligence Engineering \& Sciences Publication

(C) Convriaht: All riahts reserved. 


\section{LATERAL SUPPORT STRUCTURES AND CLASSIFICATION OF THEIR MECHANISMS}

Retaining structures are mainly applicable in cases of soil discontinuity caused by an excavation beneath the natural surface of the soil, such as when digging roads in difficult geographical terrain with steep slopes [6].

There is a wide variety of structures used to retain soil and water for both temporary and permanent works [7].

Depending on the type of construction the support works are as follows:

- Retaining walls

- Gravity walls

- Cantilever walls

- Anchored walls

- Berlin walls

- Ground support constructions (Sheet pile walls, Diaphragm walls, etc.).

The retaining structures can be classified according to the concept of "displacement" based on three criteria:

- The newest criterion, with a basic support mechanism, in which the retainers are stabilized either externally or internally and stabilize the excavations or landfills in a very different way.

Externally stabilized retainers are those in which the ground pressures add up, producing an overall action that the retainer is required to sustain.

Internally stabilized systems, such as the reinforced earth, are called systems in which the soil mass is shared so that each part of it is supported by a locally reinforcing element (e.g. reinforcement).

- A second criterion classifies the retainers according to the geomaterial retained.

- Finally, the oldest classification criterion separates the retainers according to the size of the pressures applied, ranging from zero to the free slope (natural material) to the condensation pressures on the artificial earthy materials of the landfill. The displacements here are taken as uncontrolled, that is to say, because of the "earth pressures at rest", the displacement of the system was zero, so that the entire scientific community would spend on static analysis with the aim of dimensioning the bearer [8].

Another discrimination between the retaining structures is based on the life span of each construction. Thus, the gravity walls are characterized as permanent structures for receiving ground loads. Because of their permanent nature, it is important to realistically predict the long-term effects that the system is going to be subjected to [9].

\section{RETAINING WALLS SIMULATIONS}

For this construction cost analysis, three retaining wall simulations, a Gravity wall, a Cantilever wall, and a Braced wall were created. These walls are studied for specific soil conditions in order to evaluate the final construction costs. Key parameters taken into account for the study of each wall separately are:

- External stability factor: $2<$ FS $<2.4$

- Wall height: 4 meters

- Two-layer soil profile

- Presence of aquifers

- Permissible ground stress $\sigma=0.15 \mathrm{MPa}$.

The study steps include the wall analysis settings, the geometry and the material of each wall as well as the number and corresponding thicknesses of the soil layers of the supported terrain. Two layers of soil were used in the present work, the first of which consists of sand and the second of clay. These initial settings are presented in the tables 1, 2 and 3:

Table- I: Wall analysis settings

\begin{tabular}{|c|c|}
\hline Analytics settings: & Standard - safety factors \\
\hline Concrete structures: & EN 1992-1-1 (EC2) \\
\hline Coefficients EN 1992-1-1: & standard \\
\hline Bearing masonry: & EN 1996-1-1 (EC6) \\
\hline Calculation of active earth pressure: & Coulomb method \\
\hline Calculation of passive land pressure: & Coulomb method \\
\hline Seismic analysis: & Mononobe-Okabe \\
\hline Ground wedge shape: & Calculation as oblique \\
\hline Eccentricity permitted: & 0.333 \\
\hline Verification Methodology: & Safety Factor (ASD) \\
\hline
\end{tabular}

Table- II: Specification of materials

\begin{tabular}{|l|l|}
\hline Concrete: & $\mathbf{C 2 0} / 25$ \\
\hline Cylinder compressive strength: & ck $=20 \mathrm{MPa}$ \\
\hline Tensile strength: & $\mathrm{fctm}=2.20 \mathrm{MPa}$ \\
\hline Longitudinal steel: & $\mathbf{B 5 0 0}$ \\
\hline Steel strength: & $\mathbf{f y} \mathbf{k}=500 \mathrm{MPa}$ \\
\hline
\end{tabular}

Table- III: Specification of materials

\begin{tabular}{|l|l|l|l|}
\hline 1st Soil layer: & Sand & 2nd Soil layer: & Clay \\
\hline Specific weight: & $\gamma=18 \mathrm{kN} / \mathrm{m}^{3}$ & Specific weight: & $\gamma=18 \mathrm{kN} / \mathrm{m}^{3}$ \\
\hline Stress state: & active & Stress state: & active \\
\hline Internal friction angle: & $\varphi e f=40^{\circ}$ & Internal friction angle: & $\varphi e f=29^{\circ}$ \\
\hline Cohesion: & Cef $=0 \mathrm{kPa}$ & Cohesion: & $\mathrm{Cef}=5 \mathrm{kPa}$ \\
\hline Wall-soil friction angle: & $\delta=0$ & Wall-soil friction angle: & $\delta=0$ \\
\hline Soil class & inconsistent & Soil class & $\mathrm{cohesive}$ \\
\hline Saturated Soil Specific Weight: & $\gamma s a t=18 \mathrm{kN} / \mathrm{m}^{3}$ & Saturated Soil Specific Weight: & $\gamma \mathrm{sat}=20 \mathrm{kN} / \mathrm{m}^{3}$ \\
\cline { 2 - 4 } & & Poisson's ratio & $v=0.30$ \\
\end{tabular}

\section{Case 1: Gravity Wall}

It should be noted that in the process of the geometry design of each wall, different dimensional values were examined until the final dimension of the width was obtained, so as to meet the requirement of the safety factor, $2<\mathrm{FS}<2.4$. Figures 1, 2 and 3 show the geometry of the Gravity wall, its three-dimensional representation as well as the schematic analysis of its stability. The safety factor resulted is $2.34>2$.

Published By:

Blue Eyes Intelligence Engineering

\& Sciences Publication

(C) Convriaht: All riahts reserved.

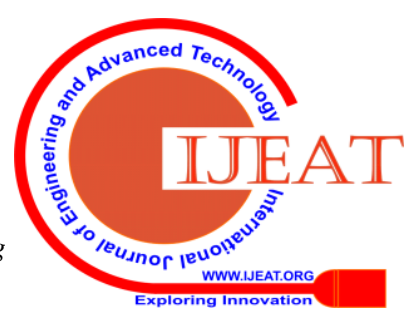




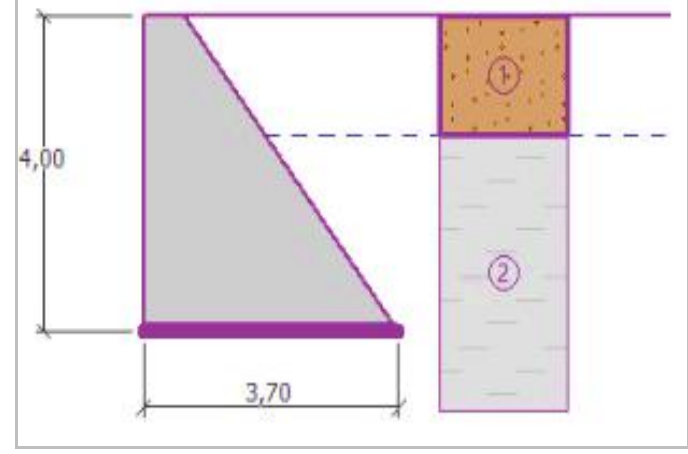

Fig. 1. Gravity wall geometry

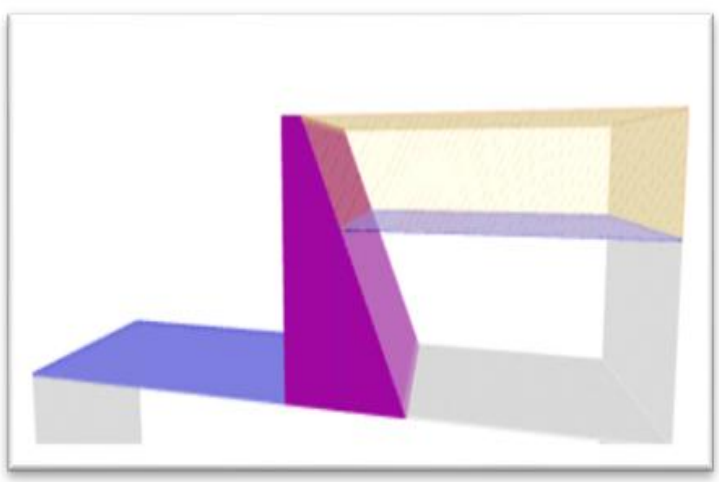

Fig. 2. Gravity wall 3D illustration

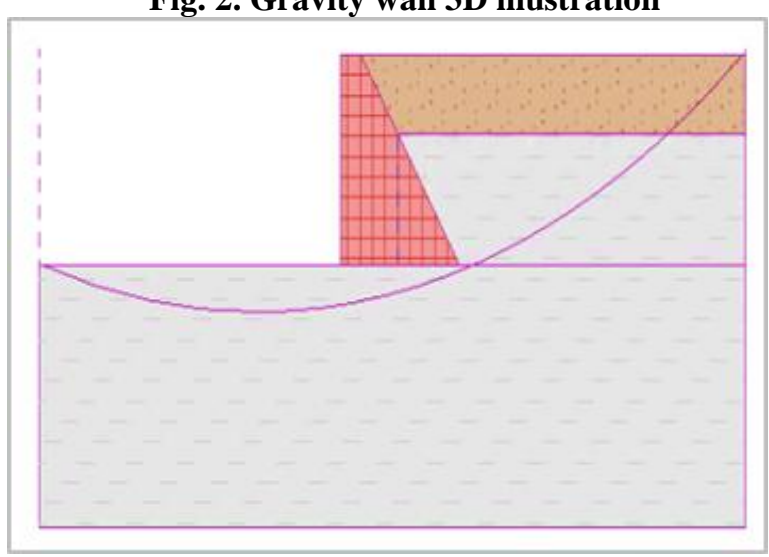

Fig. 3. Gravity wall stability analysis

\section{Case 2: Cantilever Wall}

In the second case, a cantilever wall with the dimensions shown in Figure 4 is studied in the same way. In addition, Figure 5 gives the three-dimensional image of the Cantilever wall.

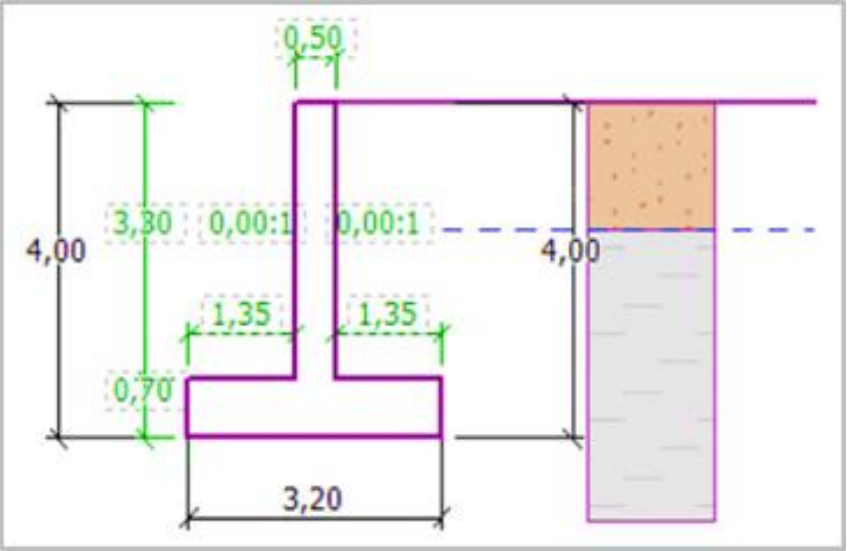

Fig. 4. Dimensions of the Cantilever wall

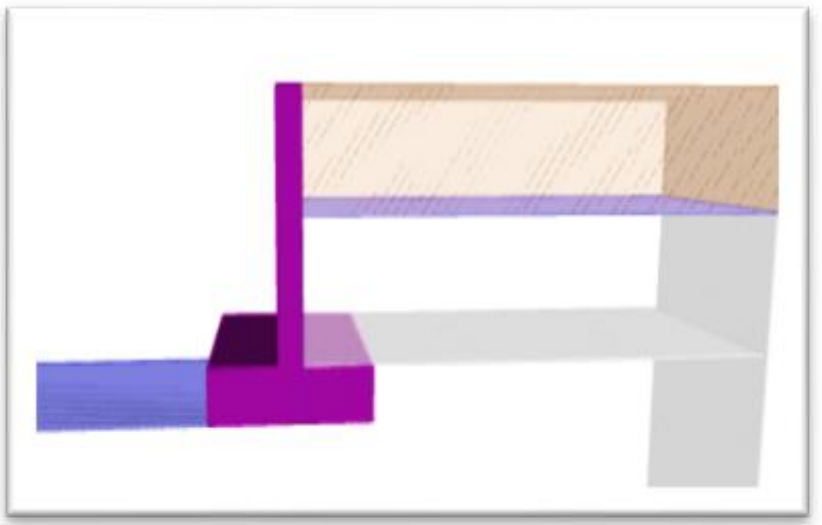

Fig. 5. Three-dimensional Cantilever wall illustration Next step in the Cantilever wall design is the stage of selecting the wall reinforcement. In this wall, as that in the third case, the minimum reinforcement required with a rod diameter $\varnothing 14$ is used. The checking positions of the reinforced cross-sections are at the vertical trunk and at the foot of the wall. After completing these steps, stability analysis was performed (Figure 6), using the Bishop method. The safety factor resulted is $2.37>2$.

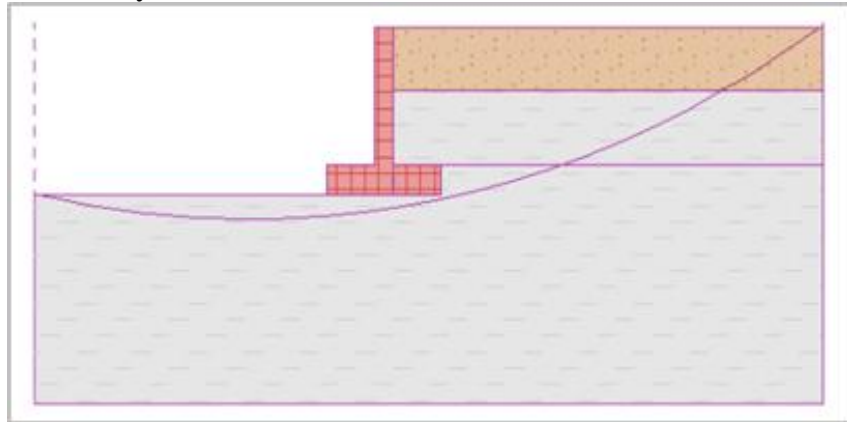

Fig. 6. Cantilever wall stability analysis Case 3: Braced Wall

In the third case, a wall with two brackets, with the dimensions shown in Figure 7 is studied. Figure 8 shows the three-dimensional representation of the wall.

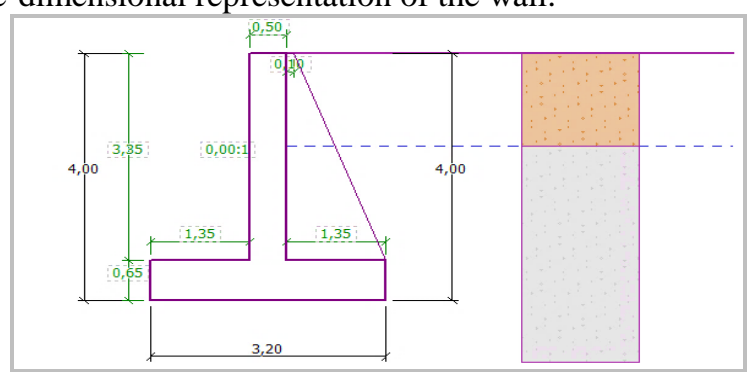

Fig. 7. Wall dimensions with brackets

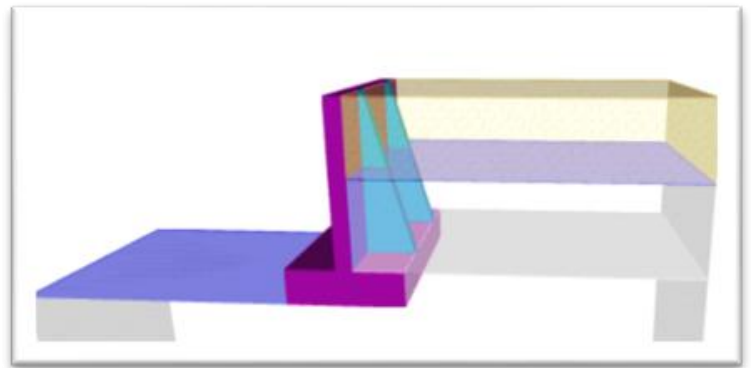

Fig. 8. Three-dimensional illustration of wall with brackets

Published By:

Blue Eyes Intelligence Engineering \& Sciences Publication

(C) Convriaht: All riahts reserved.

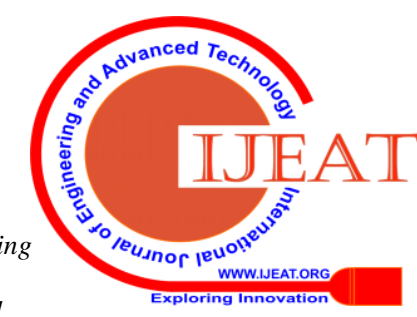




\section{Construction Cost Analysis of Retaining Walls}

The dimensions of each bracket (Figure 9) are:

\begin{tabular}{|r|l|}
\hline Distance: & $\begin{array}{l}\mathrm{l}=2.50 \\
(\mathrm{~m})\end{array}$ \\
\hline Thickness: & $\begin{array}{l}\mathrm{b}=0.25 \\
(\mathrm{~m})\end{array}$ \\
\hline $\begin{array}{r}\text { Upper } \\
\text { Width: }\end{array}$ & $\begin{array}{l}a_{1}=0.10 \\
(\mathrm{~m})\end{array}$ \\
\hline
\end{tabular}

After completing these steps, stability analysis was performed (Figure 10), using the Bishop method. The safety factor resulted is $2.37>2$.

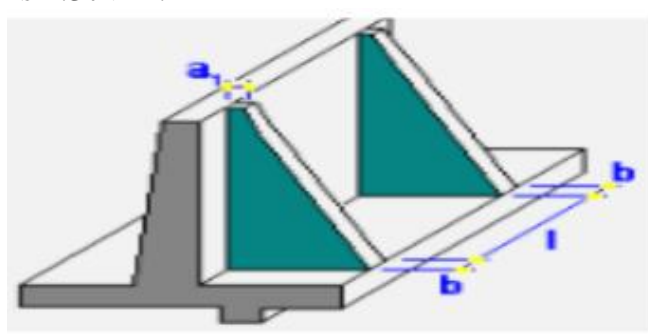

Fig. 9. Dimensions of brackets

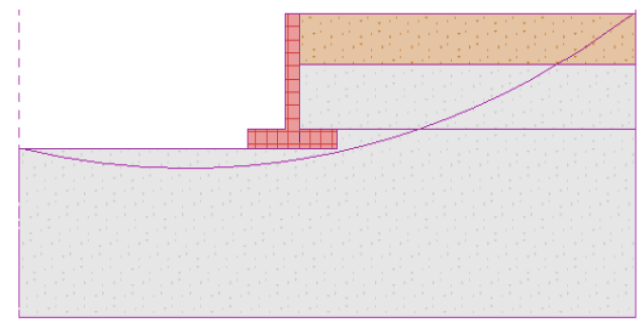

\section{Fig. 10. Stability analysis of the Braced wall}

\section{Construction Cost AnAlysis}

After the stability analysis of each wall separately, the aim was to examine their cost of construction. The construction prices taken in the analysis are the current market prices and were obtained by questionnaires submitted to technical businesses that undertake similar works. The materials that have been used for the construction of the walls, as already mentioned, are concrete and reinforcing steel. However, in addition to the cost of each material separately, labor costs were also taken into account. As for the cost of both the concrete and the use of pump, which is calculated with VAT, the corresponding price is $70 € / \mathrm{m}^{3}$ and the labor price $35 € / \mathrm{m}^{3}$. The cost of steel reinforcement is $0.9 € / \mathrm{kg}$ and installation cost is $0.11 € / \mathrm{kg}$.

In addition, the necessary parameters to estimate the cost of the quantities of the materials for the construction of the walls are the wall cross section, calculated using the Autocad software and the weight of the steel bars, for a diameter of 14 mm used, taken equal to $1.21 \mathrm{~kg} / \mathrm{m}$ [10]. Cost analysis was performed using the Microsoft Excel software. The calculations and the results of the construction costs are referred in euros per current meter of the walls. Table 4 presents analytically the calculated construction costs.

Table- IV: Calculation of the construction costs of the three retaining walls

\begin{tabular}{|c|c|}
\hline Specific weight of concrete: & $23 \mathrm{kN} / \mathrm{m}^{3}$ \\
\hline Steel bar weight $(\varnothing 14)=$ & $1,21 \mathrm{~kg} / \mathrm{m}$ \\
\hline Price of Concrete Pump with VAT $=$ & $70 € / m^{3}$ \\
\hline Labor costs & $35 € / m^{3}$ \\
\hline Cost of reinforcement & $0,9 € / \mathrm{kg}$ \\
\hline Cost of reinforcement mounting & $0,11 € / \mathrm{kg}$ \\
\hline \multicolumn{2}{|c|}{ GRAVITY WALL } \\
\hline Wall cross section area: $A=$ & $8,6 \mathrm{~m}^{2}$ \\
\hline Wall volume $=A \times 1 \mathrm{~m}=$ & $8,6 \mathrm{~m}^{3}$ \\
\hline Wall weight & $8,6 \mathrm{~m}^{3} \times 23 \mathrm{kN} / \mathrm{m}^{3}=197,8 \mathrm{kN}$ \\
\hline Cost of concrete & $8,6 \mathrm{~m}^{3} \times 70 € / \mathrm{m}^{3}=602 €$ \\
\hline Labor costs & $8,6 \mathrm{~m}^{3} \times 35 € / \mathrm{m}^{3}=301 \epsilon$ \\
\hline TOTAL CONSTRUCTION COST & $903 \epsilon / m$ \\
\hline \multicolumn{2}{|c|}{ CANTILEVER WALL } \\
\hline Wall cross section area: $A=$ & $3,89 \mathrm{~m}^{2}$ \\
\hline Wall volume $=A \times 1 \mathrm{~m}=$ & $3,89 \mathrm{~m}^{3}$ \\
\hline Wall weight & $3,89 \mathrm{~m}^{3} \times 23 \mathrm{kN} / \mathrm{m}^{3}=89,47 \mathrm{kN}$ \\
\hline Total steel bars per current meter of the wall: & $16 \mathrm{~kg}$ \\
\hline Weight of reinforcement & $16 \times 1,21 \mathrm{~kg} / \mathrm{m}=19,36 \mathrm{~kg} / \mathrm{m}$ \\
\hline Cost of concrete & $3,89 \mathrm{~m}^{3} \times 70 € / \mathrm{m}^{3}=272 €$ \\
\hline Labor costs & $3,89 \mathrm{~m}^{3} \times 35 € / \mathrm{m}^{3}=136 €$ \\
\hline Total cost of concrete $=$ & $408 € / m$ \\
\hline Cost of reinforcement & $19,36 \mathrm{~kg} / \mathrm{m} \times 0,9 € / \mathrm{kg}=17,24 € / \mathrm{m}$ \\
\hline Cost of reinforcement mounting & $19,36 \mathrm{~kg} / \mathrm{m} \times 0,11 € / \mathrm{kg}=2,14 € / \mathrm{m}$ \\
\hline Total cost of reinforcement $=$ & $19,55 € / m$ \\
\hline TOTAL CONSTRUCTION COST & $428 € / m$ \\
\hline \multicolumn{2}{|c|}{ BRACED WALL } \\
\hline Bracket Thickness: $b=$ & $0,25 \mathrm{~m}$ \\
\hline Wall cross section area: $A T=$ & $3,755 \mathrm{~m}^{2}$ \\
\hline Bracket Area: Ref & $2,428 \mathrm{~m}^{2}$ \\
\hline Volume $T=A T \times 1 \mathrm{~m}=$ & $3,755 \mathrm{~m}^{3}$ \\
\hline Bracket Volume & $\left(2,428 \mathrm{~m}^{2} \times 1 \mathrm{~m} \times 0,25\right) \times 2=1,214 \mathrm{~m}^{3}$ \\
\hline
\end{tabular}

Published By:

Blue Eyes Intelligence Engineering \& Sciences Publication

(C) Convriaht: All riahts reserved. 


\begin{tabular}{|r|l|}
\hline Total wall volume $=$ & $3,755 \mathrm{~m}^{3}+1,214 \mathrm{~m}^{3}=4,696 \mathrm{~m}^{3}$ \\
\hline Weight T $=$ & $3,755 \mathrm{~m}^{3} \times 23 \mathrm{kN} / \mathrm{m}^{3}=86,365 \mathrm{kN}$ \\
\hline Bracket Weight $=$ & $\left(1,214 \mathrm{~m}^{3} \times 23 \mathrm{kN} / \mathrm{m}^{3} \times 0,25\right) \times 2=27,922 \mathrm{kN}$ \\
\hline Total wall weight $=$ & $4,969 \mathrm{~m}^{3} \times 23 \mathrm{kN} / \mathrm{m}^{3}=114,287 \mathrm{kN}$ \\
\hline Total steel bars $/ \mathrm{m}$ wall: & 73 \\
\hline Weight of reinforcement & $73 \times 1,21 \mathrm{~kg} / \mathrm{m}=88,33 \mathrm{~kg} / \mathrm{m}$ \\
\hline Cost of concrete & $4,969 \mathrm{~m}^{3} \times 70 € / \mathrm{m}^{3}=348 €$ \\
\hline Labor costs & $4,969 \mathrm{~m}^{3} \times 35 € / \mathrm{m}^{3}=174 €$ \\
\hline Total cost of concrete $=$ & $522 € / \mathrm{m}$ \\
\hline Cost of reinforcement & $88,33 \mathrm{~kg} / \mathrm{m} \times 0,9 € / \mathrm{kg}=79,49 € / \mathrm{m}$ \\
\hline Cost of reinforcement mounting & $88,33 \mathrm{~kg} / \mathrm{m} \times 0,11 € / \mathrm{kg}=9,74 € / \mathrm{m}$ \\
\hline Total cost of reinforcement $=$ & $89,21 € / \mathrm{m}$ \\
\hline TOTAL CONSTRUCTION COST & $611 € / \mathrm{m}$ \\
\hline
\end{tabular}

Figures 11, 12, 13 and 14, illustrate diagrammatic comparisons of the concrete volume, the cost of concrete, the reinforcement cost, and the total construction costs of the walls.

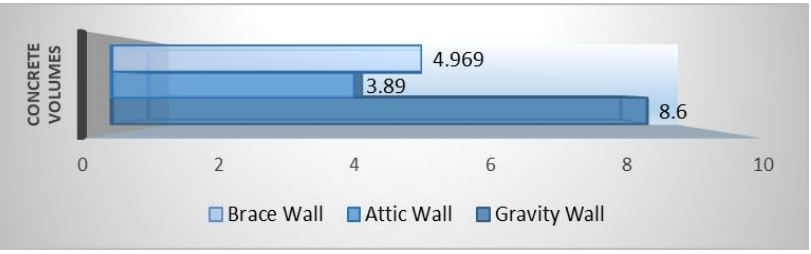

Fig. 11. Comparative chart of required volume of concrete for each wall

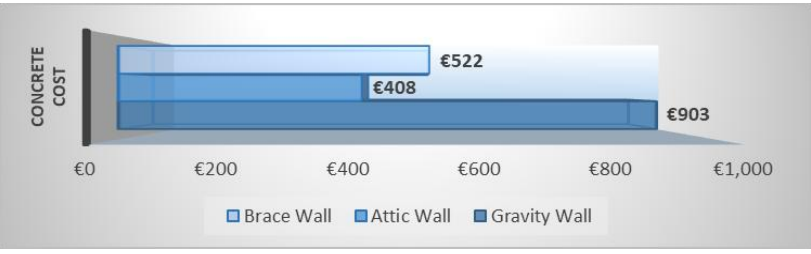

Fig. 12. Comparative cost chart of required concrete

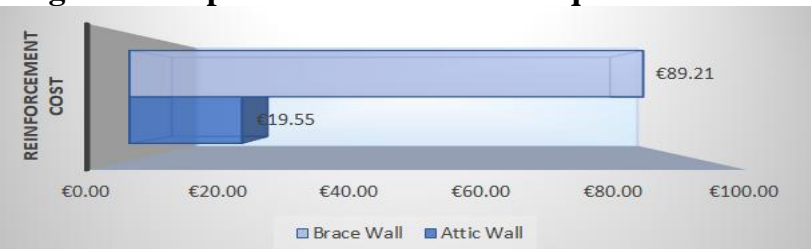

Fig. 13. Cost Comparison Diagram of Requirement for Attic Wall and Brace Wall

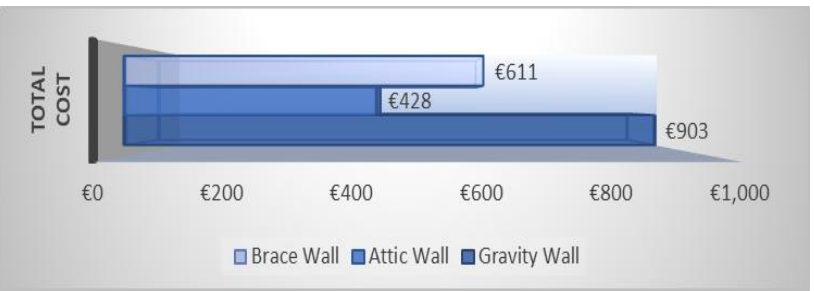

Fig. 14. Gravity wall geometry

\section{SUGGESTIONS}

The aforementioned cantilever walls are more economical than conventional gravity walls, as they utilize the weight of the soil mass above the foot of the wall. Their design can be further improved through appropriate dimensioning [11].

The retaining walls must be mounted at a depth greater than $0.6 \mathrm{~m}$ from the surface of the adjacent soil [12].

When laying the foundation concrete separately from the wall, one or more joints must be formed in the concrete slab-wall junction. This is performed to enable the cross-section to assume a shear force greater than that due to friction.

\section{CONCLUSIONS}

The purpose of the present work is to approach and study the stability and the construction cost of the retaining walls. Historically, the impact of lateral pressure on constructions was one of the first problems of geotechnical engineering. In trying to approach the problem some of the first and most basic principles of Soil Mechanics were developed. In order to achieve the goals, three simulations were produced and solved using appropriate software: a gravity wall, a cantilever wall and a bracket wall.

These walls are studied by assuming similar soil characteristics. The basic assumption of the study is the external stability factor with the desired range of calculation: $2<$ FS $<2$.4. In particular, each wall separately supports a 4-meter two-layer soil profile with the presence of an aquifer. Bearing the above in mind, the authors come to the following conclusions:

1. Relative to the concrete used in each wall, the gravity wall is the largest wall in volume compared to the other two. Specifically, its cross-section area is $8.6 \mathrm{~m}^{3}$, the Brace Wall follows with $4.97 \mathrm{~m}^{3}$ and finally the cantilever wall with $3.89 \mathrm{~m}^{3}$. Of course, this has a direct impact on the cost of concrete, as the final cost of the gravity wall is $€ 903 /$ current meter. Less costly, concerning the cost of concrete, is the Brace Wall at 522 $€ /$ current meter and finally the cantilever wall at 408 $€ /$ current meter.

2. The comparison that has been carried out is related to the required reinforcement of the Cantilever wall versus the Brace Wall regarding their construction. The cantilever wall in particular requires a much smaller reinforcement weight per current meter than the brace wall. Specifically, the weight of reinforcement per current meter of the Cantilever wall is $19.36 \mathrm{~kg}$ and for the Brace Wall the figure is $88.33 \mathrm{~kg}$. Analogous is the impact of this, again, on the overall picture of costs, taking into account the price of reinforcement and the price of its installation. Specifically, the cantilever wall costs $19.55 €$ /current meter and the Brace Wall 89.21 $€ /$ current meter.

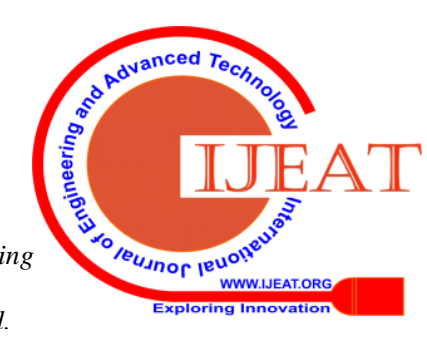


3. Furthermore, upon comparing the total cost of the walls, it can be concluded that the construction of the gravity wall becomes uneconomical given the cost price (903 $€ /$ current meter) compared to the next cheaper (Braced) in which the cost of construction is $611 € /$ current meter.

4. The cantilever wall and the braced wall, which have the same external stability factor of 2.7 , in addition to comparable costs, can be compared on the overturning and sliding safety factors. The safety factors of the cantilever wall in tilt control and in slip are 4.03 and 1.53 respectively. In contrast, bracket walls present with safety coefficient of 3.97 in tilt control and 1.51 in slip control.

5. The above results confirm that the construction of the cantilever wall is preferable in terms of/in favor of safety and is also rated as more economical at a total cost of $428 € / \mathrm{m}$ compared to the $611 € / \mathrm{m}$ of the braced wall.

\section{REFERENCES}

1. Vallas D. (1986). Restraints and Foundations. Kyriakides Bros Publications, Thessaloniki.

2. Barnes G. (2000). Soil Mechanics: Principles and Applications. Klidarithmos Publications, Athens.

3. Whitlow R. (1990). Basic soil mechanics. Longman Scientific \& Technical, Hong Kong.

4. Das B.M. (1998). Principles of Foundation Engineering. PWS Publishing Company, Boston Publisher: Brooks/Cole ISBN 10: 0534954030.

5. https://www.geosoftware.gr/geotechnical-software/.

6. Morgenrstern N.R. and Price V.E. (1965). The analysis of the stability of general slip surfaces, Geotecnique, Vol. 15, 79-93.

7. Barnes G.E. (1995). Soil Mechanics: Principles and Practice. MacMillan press Ltd, Malaysia.

8. Kostopoulos S. (1998). Geotechnical Constructions. University Notes, Department of Civil Engineering, University of Thessaly, Volos.

9. Mylonakis G., Kloukinas P. and Papantonopoulos C. (2007). An Alternative to the Mononobe-Okabe Equations for Seismic Earth Pressures. Soil Dynamics and Earthquake Engineering. Volume 27, Issue 10, Pages 957-969.

10. Chouliaras I.G. (2003). Reinforced concrete constructions. Papasotiriou Publications, Athens.

11. Kloukinas P. (2012). Contribution to static and dynamic analysis of retaining walls through theoretical and experimental methods. Doctoral Dissertation University of Patras Polytechnic School, Civil Engineering Department, Patras 2012.

12. Marketos E.G. (1984) Soil Mechanics and Foundations Courses, Athens 1984.

\section{AUTHORS PROFILE}

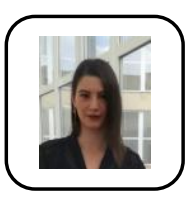

Aikaterini Alexiou. Civil Engineer T.E. (Technological Educational Institute of Thessaly, 2017). She obtained her Master's degree in Advanced Environmental Management Technologies in Engineering Works (General Department of Larissa, University of Thessaly, 2019). She is attending seminars at the National Kapodistrian University of Athens on Geographical Information Systems (GIS). She is active in the field of civil engineering. Specifically, she has worked for a construction company undertaking construction surveys, road construction surveys and cadastral surveys. She has also worked for a company that conducts geotechnical surveys. This collaboration gave her the opportunity to gain research interest in Soil Mechanics. In addition, her research interests include correlation of soil strength and soil properties, stability of slopes.

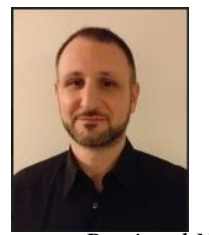

Dimos Zachos. Civil Engineer T.E. \& Mechanical Engineer T.E. (Technological Educational Institute of Thessaly). M.Sc. in Advanced Environmental Management Technologies in Engineering Works (General Dept. of Larissa, University of Thessaly).
Member of professional and scientific association of technological education engineers. He was a laboratory associate and external collaborator of research projects of the Mechanical Engineer Dept. of TEI of Thessaly. He has published papers in international peer-reviewed journals and conferences at the field of strength of materials. Research interests: dynamic strength of metal and composite materials, 3D design and analysis of structures using FEM, strength stability of soil retaining wall.

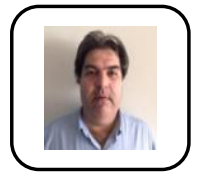

Dr. Nikolaos Alamanis. Assistant Professor PhD in Stability of Slopes (University of Thessaly, Dept. of Civil Engineering), D.E.A (Msc) Mécanique des Sols-Structures (Ecole Centrale Paris), MEng, BEng in Civil Engineering (integrated master from National Technical University of Athens, School of Civil Engineering). Member of Technical Chamber of Greece, Member of Hellenic Association of Civil Engineers, Member of American Society of Civil Engineering. He has professional experience of 32 years as an engineer and 25 years in teaching graduate and postgraduate civil engineering subjects. He has published papers in international peer-reviewed journals and conferences at the field of Geotechnical Engineering and Infrastructure Works. Research interests: stability of slopes, retaining walls, retaining systems for deep excavations, spatial variability of soil properties, autocorrelation and cross correlation of soil strength parameters.

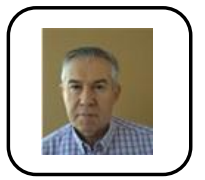

Dr. Ioannis Chouliaras. Professor, University of Thessaly, Larissa, Greece. Civil Engineer (Democritus University of Thrace, 1980). He obtained his Master's degree in Construction Management and Economics from ASTON University in Birmingham in1982. He holds his Ph. D degree from Aristotle University of Thessaloniki in 2000 with doctoral thesis "Hydraulic erosion. Study of the erodibility of cohesive geomaterials". He has professional experience of 39 years as an engineer, 34 years in teaching graduate and postgraduate civil engineering subjects and 22 years in positions of responsibility in the TEI of Thessaly. He participated in 6 research and in 9 EPEAEK programmes, published 27 scientific articles and wrote a textbook. He supervised 15 postgraduate and 51 graduate students' theses. His research interests include Soil Mechanics, Environmental Geotechnics, Project Management, Reinforced Concrete and Research Methodology.

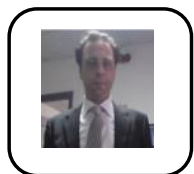

Dr. Grigorios Papageorgiou. Assistant Professor, University of Thessaly, Larissa, Greece. PhD in Transport Infrastructure Management (University of Thessaly, Dept. of Civil Engineering), MSc in Environmental Design of Infrastructure Works (Hellenic Open University, School of Science and Technology), MSc in Environmental Design of Cities and Buildings (Hellenic Open University, School of Science and Technology), Member of Technical Chamber of Greece, Hellenic Association of Civil Engineers, Hellenic Institute of Transportation Engineers. He has published papers in international peer-reviewed journals and conferences at the field of Transport Infrastructure Management. Research interests: smart roads, pavement management, environmental road design, highway infrastructure optimization. 